УДК 821.163.4-32.09 Ковач, Мирко https://doi.org/10.18485/godisnjak.2020.15.14

Милан Д. Вурдеља*

Универзитет у Београду

Филолошки факултет
Оригинални научни рад

Примљен: 15. 09. 2020.

Прихваћен: 10. 11. 2020.

\title{
„НЕДОКАЗИВА НОЪ ЖИВОТА”: ИМАГОЛОШКО ТУМАЧЕЊЕ ПРИПОВЕТКЕ ДАН И НОЋ МИРКА КОВАЧА
}

\begin{abstract}
Међу тематским преокупацијама Мирка Ковача - какве су појаве насиља, процеси успостављања и разарања идеологија, или сустицање еротског и танатичког принципа - поуздано се мора наћи и вишесмислени проблем односа појединца према другости. Штавише, ово директно дефинише неколике стилске, стилско-наратолошке и сензибилитетске одлике Ковачевих текстова. Могло би се, наиме, приметити да проблем Другог заузима повлашћено и надређено место унутар Ковачевог имагинаријума. Будући по многим својим уметничким карактеристикама надовезана на Ковачев опус који јој претходи - у првом реду на светоназор какав је заступљен у Ранама Луке Мештревића, Малвини и Вратима од утробе - приповетка „Дан и ноћ”, оригинално штампана у збирци Небески заручници, такође маркира низ варијација на тему односа према Другом.
\end{abstract}

Кључне речи: Небески заручници, Мирко Ковач, uncanny, злочин, теодицеја, перформативност идентитета.

Нагло пробуђено интересовање теоријских школа из друге половине XX века за категорију „другости” у вези са различитим психолошким, социолошким, па и естетичким феноменима, може се разумевати као последица претежне постструктуралистичке оријентације тог периода.

*milan.vurdelja93@gmail.com 
Уклањајући представу о интегралном или монолитном субјекту, ова теоријска стремљења налазила су изазовним све оно што почива на релативизовању објективног сазнања, тако да се и идеја о измештању субјективитета у фигуру Другог нарочито прожела са њима.

Имаголошка дисциплина се, међу другим постструктуралистичким тенденцијама, суверено и убрзано почела развијати шездесетих година прошлог века. На плану такозване „идентитетске политике”, тада теоријска мисао полако мења парадигму, тако да се може рећи како се: „[...] културне разлике почињу изучавати више са становишта перформативности и периептивности, него са становишта есенцијалности"1.

Уосталом, рано је потврђено како имагологија „сретно мири две области интереса: књижевност и њену друштвену основу, тај општи културни и друштвени фон на којем се стварају велике идеје које свој одјек неминовно налазе у књижевности" (Секеруш 2001: 51). Пошто у незанемарљивој мери зависи од назначеног друштвеног фона на ком се одиграва књижевна производња, имагологија је у знатној комуникацији са теоријама културе и културалним истраживањима (cultural criticism). Одатле произилази и много чешћа идеолошка освешћеност или пак острашћеност имаголога у односу на представнике других књижевнотеоријских приступа. Томе је разлог генерално интердисциплинарно усмерење културалних истраживања:

Уместо да прихвате једну методу анализе, културална истраживања [...] поступају онако како налажу њихови најрадикалнији заговорници с обзиром на изразит политички циљ каква је моћ реалног утицаја на друштвену стварност (Бужињска, Марковски 2009: 571).

Идентитет у том смислу постаје тема са безмало нежељеним дејством с којим теоретичари или мислиоци другачијих стремљења рачунају, јер се иста „призива да осветли непостојану, вишеструку, пролазну и распарчану природу савремног 'јаства"” (Брубејкер/Купер 2003: 418). Притом, идентитет постаје опсесивна имаголошка тема и због чињенице да се исти не може посматрати као подручје искључиво личног, слободног избора и поступања, јер такви избори произилазе и из „стања увијек-већ-наговорености Другим којему ми увијек само одговарамо” (Бити 2000: 191).

С филозофским предумишљајем, потребно је нагласити да је Друго у знатно претежнијем броју случајева у фикцији Мирка Ковача представљено као изразито другачије. Управо из ове чињенице проистиче

${ }^{1}$ Наиме:,,[...] cultural difference has come to be studied in terms of attitudes and perceptions rather than essences" (превод са енглеског: М. В., искључиво за потребе овог рада). Извор: imagologica (вебсајт који уређује холандски имаголог Џозеф Теодор Лирсин). 
драматичност сукоба међу јунацима, те специфично мучеништво које се за њих везује готово амблематски. Још од својих књижевних почетака, наиме, Ковач је настојао да укаже на сву комплексност учешћа појединца у историјскм токовима који га по перфидности своје непредвидљивости увелико надилазе и, најчешће, савлађују. Због тога се феномен мучеништва везује и за јунаке који су изузетни негативци, злочинци и мучитељи, и Ковач потцртава овај парадокс, сугеришући тиме колике су димензије историјског хаоса. Запажено место међу оваквим карактерима припада лику фратра Веселка Куљића, централном јунаку приповетке „Дан и ноћ”. Образлагање запретене мреже његових односа према Другом који се - што је интервенција која се не може игнорисати - огледају и у интериоризацији (мета)дијалога у самог јунака, биће у даљем току рада спроведено са имаголошког становишта, с претпоставком да ће овакав приступ обезбедити разноврсност увида.

\section{1. О гласу, „њему самом непознатом”}

Приповедачка ситуација којом отпочиње „Дан и ноћ” у многоме је андрићевска. Тачније, Ковачев приповедач сасвим подсећа на фамозног младића из пролога Проклете авлије. Баш као Андрићевог актера, и Ковачевог приповедача запала је дужност да попише оставштину покојног фра Веселка и, по већ слућеном механизму, управо ће му то пружити изворе (фратрове бележнице) и грађу за причу. Неименовани Ковачев приповедач је, према томе, претежно хетеродијегетички, говорећи женетовском терминологијом. У својој приповести, међутим, он неминовно врши својеврсну редакцију фратрове писане оставштине, чиме ипак пристрасно обликује и сиже. Због тога он не поседује неупитност објективне приповедачке инстанце.

Од каквог је ово значаја за имаголошку проблематику у приповеци? Увученост приповедача у мрачне исечке из биографије фра Веселка тиче се и категорије другости која се између њих успоставља. На једном месту приповедач вели: „Ми из православне парохије вазда смо са стрепњом чекали, кад дође до смене, какав ли је католички поп који преузима жупу, какве је нарави и душе, како је расположен према нама, је ли загрижен и прзница?" (Ковач 2001: 237).

Врло рано, дакле, у причу је уведен мотив тензије на бази конфесионалног опредељивања. Припадност православној или католичкој заједници наративизује се као питање од нарочитог значаја по идентитетско конституисање ликова или покушај таквог конституисања. Елемент стрепње и 
бојазни непрестано ће притискати свакодневицу етнички и конфесионално хетерогеног, али изразито контактног подручја - јер и сам приповедач указује на то како су православни и католици у његовом завичају били непрестано упућени једни на друге.

Из таквог амбијента, приповедач постепено издваја и чини најуочљивијим портрет фра Веселка Куљића, једног од оних двоструких фикционалних идентитета чији је главни репрезент у Ковачевом опусу лик Малвине Трифковић. Фра Веселко је - а што представља сижејну окосницу приповетке - представник тешко сводиве и застрашујуће људске судбине која се на парадоксалан начин остварује у ратним временима: преко дана као доброчинитељска (спасавање српских породица од усташког погрома), а преко ноћи као крвничка (немилосрдно ликвидирање истих породица). У циљу експликације све комплексности овог лика, потребно је поћи од најочигледнијег и највише очекиваног питања: да ли фра Веселко своја ноћна зверства чини из разлога националистичке мржње према свему што има предзнак српског?

На ово питање наводи са̂м емоционални интензитет с којим, фуриозно и као у каквој распомамљености, фратар убија. С друге стране, нема сумње да су ови тренуци обележени посебним удвајањем личности, злокобном метаморфозом кроз коју фратар пролази, а која је, симболички врло бременито комплементарна смени дана и ноћи. По светлости дана фра Веселко не само што не одаје никакав анимозитет према српском народу већ се у току крвавих видовданских прогона, како приповедач наводи, са продикаонице залаже за мир и љубав са суседима, у складу са најеклатантнијим католичким учењима. Штавише, фра Веселко показује посебан морални интегритет, будући да своме, хрватском народу, проказује усташко политичко вођство као инкриминисано.

У вези са радикалном дискрепанцијом између два вида јунаковог поступања и светоназора, нужно је обратити се базичном појму имагологије - имажу (слика, представа). Чиниоци фратровог аутоимажа у приповеци нису обелодањени директно. Ипак, понешто се о томе може дознати из начина на који је обликиван хетероимаж српске културе, као оне која је посебно упечатљиво сагледана из перспективе главног јунака. Најпре се, у једном тренутку пре судбоносног утонућа у злочин, не увиђају трагови фратрог анимозитета или зазора према Србима. Штавише, приповедач скреће пажњу на изразити алтруизам који фратар по овом питању показује. Што је необично, наводи се суштински отклон који фратар прави према муслиманима који представљају трећи културолошки елемент у, претпоставићемо, херцеговачком менталитетском простору, Ковачу толико 
омиљеном. Реч је о следећем изводу: „Кад се јутром или предвече огласи хоџа с мунаре, затварао је прозор да не слуша. Не може се рећи да их је мрзео, само је жалио што су то некад били хришћани, а да је среће опет би то могли постати" (Ковач 2001: 239).

На основу фратрових реплика које су упућене његовом будућим жртвама, а затим суровости и бешћутности којима су обележена сама убиства, хетероимаж представника српског народа чине превасходно квалитети нечега страног, одбојног и неразумљивог, а што надаље производи импулсивну мржњу према себи. Она није толико „разговетна”, као што је то фратрова одбојност према муслиманима. Овај хетероимаж је, поновити ваља, стриктно условљен тачком гледишта која припада главном јунаку. Он нема покрића у ликовима Срба уколико се они разматрају засебно или изоловано.

У том случају, имагинирање се у првом реду завршава у слици недужне жртве. Тврдња се лако поткрепљује неколиким епизодама које приказују страдање оних који су, испрва, били планирани за спас од прогона. Опис првог фратровог злочина се довољно упечатљиво заснива на мотиву невиног страдалника, поготово зато што је у тој улози девојчица Круна, ћерка српског газде Спајића у чију кућу долазе усташе с јасним пљачкашким намерама.

Игром случаја део кажњеничке патроле, фра Веселко испочетка исказује недвосмислену одбојност према двојици војника, осведочених насилника. Током претреса Спајићевог имања, фратар ће бити у прилици да спасе унезверену девојчицу којој су наочиглед брутално убијени родитељи. Њена невиност додатно је поткрепљена наивношћу коју показује исповедајући се фратру. Овај ће је најпре молити да се утиша и примири да би, без икакве реалистичке мотивације, викнуо: „Умукни, кучко српска” (Ковач 2001: 243), и то гласом који је био и „њему самом непознат” (Ковач 2001: 243). Девојчица ће бешћутно бити удављена и у на идеолошком фону приповетке постаће симболом ућуткане различитости.

Појам различитости се од тог тренутка у приповеци неизоставно везује за српство и, опсервиран са етичког становишта које не искључује грубу демаркациону линију између добра и зла, представљаће жртвовање невиности, што ће рећи узмицање доброте пред навирањем зла. Страдање Јанка Симата, једног од оних не мање виђенијих Срба, смештених у центар друштвеног утицаја, такође ће доћи од каме фра Веселка, али ће претходно бити наговештено теодицејско питање. Наиме, Симата ће уз благо предосећање смрти, без икакве дубље примисли, упитати фратра зашто ризикује и помаже њему и његовој породици као представницима 
проказаног српства (дакле као алијенитетског Другог). Одговор кији ће добити од фратра колоквијалан је, али илуструје непостојаност доброчиства у ратној стихији која рачуна само на насиље према ближњем: „И ја се питам што?" (Ковач 2001: 249).

Поједини ликови Срба отворено наративизују страдалничку улогу која им је наметнута, па тако прилажу аутоимаж припадника жртвованог народа. Овај случај је заступљен у склопу описа претпоследњег фратровог убиства. Парох Стефан Кадијевић пожалиће се, наиме, фра Веселку: „Хоће ли се икад српска мука ставити на тас, хоће ли бити историје, за свето име божије? Или смо баш проклети и жртвовани?" (Ковач 2001: 258). Да ли се поводом овог примера може говорити о Ковачевом умешном преобликовању стереотипа о Србима као народу предестинираном на мучеништво, и то с хришћанским предзнаком?

С тачке гледишта појединих балканских културних политика, заиста је реч о класичном стереотипу, генерисаном и каткад заступаном од стране самих Срба. Ако се питање расветли изнутра, уз уважавање дуге традиције мартирства која је инкорпорирана најочитије у косовски мит, или у оно што је Зоран Мишић апострофирао као косовско опредељење ${ }^{2}$, биће јасније како није реч о ординарном стереотипу. Због тога овај мотив у Ковачевој приповеци има посебну тежину, и као сегмент карактеризације јунака, и као симболички приказ борбе између добра и зла.

Нема бољег примера за субјективност фратровог аутоимажа од сцене његове проповеди у православној богомољи, и по православном обреду. Наиме, свега дан након што је усмртио Јанка Симата, фра Веселко је изнова показао своје „дневно”, богоугодно лице, држећи прву проповед православној пастви након видовданских покоља, и тиме се сврставајући, само наизглед, на страну супротну усташкој страховлади.

Изразито одушевљење које верници показују према свом претпостављеном заштитнику увеличава проблематику другости као привида. Аутоимаж фра Веселка, утемељен на претпостављању хуманистичких вредности било каквим конструкцијама националне или религијске идентификације, злокобно је комплементаран фратровом хетероимажу који се образује у очима православног колектива. Тако мајка убијеног Симата, у потпуном незнању, али с правом очајничког перспективизма, фра Веселка доживљава као владику (Ковач 2001: 250). Читав овај фрагмент аргумен-

${ }^{2}$, „[...] Видећемо да је косовско опредељење онај последњи, беспризивни одговор којим се одговара на питање о смислу човековог постојања. Видећемо да је то избор оног најтежег, најпогубнијег пута, који је једини прави пут. Определити се косовски, то значи [...] усхтети његошевски да буде оно што бити не може” (Мишић 1963: 173-174). 
тује тесну повезаност имаголошке визуре са дубинском психологијом која полази од елементарних људских осећања и стања - страха и безнадежности - а која сама по себи надилазе спомињане конструктивистичке категорије.

2. Имагинирање конфесионалне и етничке другости под дејством uncanny-a

Сва имаголошка апаратура полази од разлика као услова за образовање идентитета. Разлике, као и национални, конфесионални, социјални и други идентитети, не могу се, што је скоро па самообјашњиво, изузети из своје конструктивистичке природе. Пошто су фикционални идентитети иманентно конструктивистички, разлике између њих испостављају се за посебно минуциозне. Мржња фра Веселка према свему српском је, на пример, испражења од сваког значења које би трансцендирало конструктивизам непомирљивих разлика између хрватске и српске културе.

Фратар, међутим, не исказује свој национални идентитет изван манијакалног преображаја који доноси прелазак дана у ноћ. Национални идентитет, према томе, не постоји као релевантан чинилац аутоимажа који, заправо, у осетнијој мери, дефинишу доброчинство и хришћанска брига о ближњем. Непомирљивост између тога како фратар себе имагинира и тога каква се представа злочинца за њега везује након што избију несвесни садржаји, главни је извор драматичности која одликује Ковачеву приповетку. По среди је, последично овоме, психолошки или, што је можда још тачније, парапсихолошки феномен (Калезић Ђуричковић 2014: 324) који захтева опсервацију не само са имаголошког становишта.

Као могућност за „откључавање” необичног психолошког склопа фратровог лика, то јест драстичне подвојености коју он еманира, намећу се неколика исходишта фројдовске психологије. Чини се да примењивање класичне тријаде (Id-Ego-Superego) не би било достатно у овом случају. Id као именитељ несвесног може учинити јаснијом тек природу фратровог „ноћног бића”, али не и интензитет и очуђеност с којом се исто актуелизује. Зато се обраћамо једном такође референтном Фројдовом концепту - претпоставци unheimliche-а или, како се још наводи у литератури, uncanny-a.

Познато је да термин „uncanny” представља преводилачки изазов. Иако се дословно чита као „не-фамилијарно”, по Фројдовој концепцији изложеној и есеју „Das Unheimliche” из 1919. године, термин наткриљује врло комплексан сплет психолошких стања која полазе од страха, нелагоде, зазора, анксиозности или нагона притиснутог репресијом. Штавише, фа- 
воризовање uncanny-a у психоанализи надахнуто је тумачењем необичних, дубоко непојмљивих фиктивних ситуација из текстова Ен Редклиф, Е. Т. Хофмана, Е. А. Поа и сличних аутора. Ово на посебан начин иде у прилог тумачењу лика фра Веселка из Ковачеве приповетке, као што представља херменеутичку могућност да се употпуне опсервације које су до сада изнесене кроз имаголошку визуру.

Претпоставка је следећа: фратровог абруптног гађења и мржње према српству не би било без девијантне црте у његовом карактеру, црте која се објављује као uncanny и поспешује мржњу до те мере да она резултује злочином. Да је заиста у питању литераризовани феномен појаве чудног, зазорног и узнемирујућег квалитета смештеног у Другост, доказују неколике секвенце у приповеци, махом посвећене карактеризацији главног јунака. Њих је потребно размотрити у хронолошком захвату, како би се уочио процес кроз који фра Веселко, као изразито динамичан карактер, пролази.

У експозицији приповетке, приповедач се осврће на занимљиву фратрову опсесију из најмлађих година, ону о изградњи савршеног заклона, одаје и лавиринта, што би га заувек заштитило од нечег што је „замршено и за њега недокучиво" (Ковач 2001: 237). На овом месту је већ мотивисан дубински, примордијални страх усађен у главног јунака. Бујање мрачне и деструктивне црте у фра Веселку (примерно обртање nomen est omen поступка), такође је нуминозно мотивисано: „Ноћ га је одувек мамила и заводила [...] у црној одори, промицао је као сабласт” (Ковач 2001: 239).

Коначно долазимо до феномена сабласног које, како приповетка одмиче, све више фигурира у изградњи фратровог лика. Свака епизода убијања Срба пропраћена је неким мотивом који указује на дејство uncanny-a. Обично приповедач скреће пажњу на неприродно (демонско) звучање фратровог гласа у тренуцима када га обузима мржња и када се упушта у злочин. Током убиства газда-Спајићеве ћерке вели се да му је глас био „прозукао, њему самом непознат” (Ковач 2001: 243). Вређајући изненада следећу жртву, Јанка Симата, фратар ће то учинити гласом „гадним и њему самом неугодним" (Ковач 2001: 249).

Напокон, након што га почну прогонити сећања на злодела, фра Веселко ће се плашити „властитог шапата који му се учинио сумњив и лудачки" (Ковач 2001: 254). Сви горепоменути примери упечатљиво дочаравају (пара)психолошку проблематику у приповеци „Дан и ноћ”, због које се ни имаголошка питања њоме покренута не могу посматрати изоловано. Истовремено, не сме се превиђати ни перформативни моменат при успостављању српства као (псеудо)идентитетске категорије у свету Ковачеве приповетке. 
Баш због непредвидљивсти „силе” која обузима фратра и чини га чудовишно другачијим, јасна бива чињеница да српство, чак ни са фратрове тачке гледишта која се јавља у његовом дневном/свесном бићу, не представља реалан идентитетски садржај. У неком другом контексту, фратрови злочини били би истоветни: уместо усташког политичког окружења, да је фратар затечени припадник другог културног миљеа - немачког фашизма, на пример - могли бисмо замислити да би с истом жестином кажњавао Јевреје због непостојеће кривице, онако како то чини Србима.

Учешће uncanny-a у сликању унутрашњег портрета фра Веселка, према томе, умногоме дефинише како чиниоце аутоимажа, тако и исходе његовог хетероимагирања. Последично томе, лакановско „велико Друго” („радикални алтеритет, другост која трансцендентира илузију имагинарости” (Милутиновић 2012: 201)) уписано је у српство, а никако обрнуто. Већ помињана слика невине жртве само доприноси демонизацији коју фратар укључује у свој хетероимаж Срба. Најзад, ефекти unheimliche-a далекосежан су разлог томе што метаимаж не постоји као битан део идентитета главног јунака приповетке. Будући да ни сам себе не (пре)познаје, да суштински није у стању да се суочи са силом која га обузима, фратар није способан да промишља слику себе самог, јер, на крају крајева, та слика не може бити имаж, стереотип или нека друга конструкција, већ је, у првом реду, непремостива непознаница.

Она, поврх свега, задобија карактеристике натприродног, пошто се подвојеност фра Веселка не може, у ствари, свести на контраст који одликује наслов приповетке. Ноћ као време фантастичног ослобађања главног јунака такође се може као мотив тумачити кроз призму uncanny-a. По том питању, користан је Фројдов увид по ком се uncanny актуелизује „када симбол преузме пуну функцију и значај онога што симболизује"з (Фројд 2003: 150). Симбол ноћи у Ковачевој приповеци попримио је управо димензије на које Фројд скреће пажњу.

Немогуће је, зато, дискурзивно продрети у тајну фратровог ноћног бића. Овом тајном се Ковач, транспонујући је на метатекстуални ниво збирке Небески заручници, поиграва и поводом односа аутор-читалац. И том приликом се, наиме, активира проблем двојништва. У раном приказу Ковачеве збирке се, с тим у вези, вели: „Мотив двојника аутор уграђује у дело не само као фабулу, него и као експлицитну идејну нит, као интерпретацију" (Чањи 1987: 494). Ово имплицира чињеницу да је двојништво

${ }^{3}$ Tо јест: ,when a symbol takes on the full function and significance of what it symbolizes" (превод: М. В.; искључиво за потребе овог рада). 
нека врста мета-коментара по ком се обликују разнородни нивои Ковачеве збирке.

Осим на Фројдово схватање uncanny-а, у овом светлу ваља се осврнути и на поимање „онедомаћеног” (још једна преводилачка могућност за uncanny) које је изложио Ернст Јенч. Оно је посебно интригантно јер указује на когнитивну напетост на којој почива uncanny: оно што је познато, у свом застрашујућем дејству наједном постаје непознато. Поље ове забуне може бити и сам текст, при чему је: „кључан осећај несигурности, неизвесности да ли нешто чудновато заиста постоји у свету текста, да ли неки део истине недостаје или не" (Ђурић 2017: 305). Управо се ова дилема јавља у читаоцу „Дана и ноћи”, док прати Ковачев текст који намерно не успева испратити фратрову судбину, већ је добрим дело оставља у сенци, затомљеном.

Како је идентитетски фаворизован фратров однос према националном питању, како је, другим речима, мржња према Србима - ма колико херметично посредована - утемељујућа за сиже приповетке, флуидност фратровог доживљаја нације одражава се у познатом ставу Ентонија Смита: „Трагање за националним ја и однос појединца према њему остају најзагонетнији елемент у националистичком пројекту" (Смит 1998: 34). Несумњиво се, међутим, бар део речене загонетке у случају фра Веселка објашњава његовим (не)природним, алогичним двојством: „Шкриња фра Веселка Куљића имала је два дна, баш по мери његове природе да увек и у свему постоји двојство" (Ковач 2001: 264). Зар није другим делом ове епилошке реченице исказан један принцип?

Указујући на незаобилазну сплетеност историјских датости као перформативних категорија (нације и вере) са примордијалним и метафизичким слојевима појединачног егзистирања, Ковач свој текст чини провокативним за ону, нарочито интердисциплинарну и филозофски поткрепљену струју имагологије која се не зауставља на опису генерисаних слика или стереотипа.

Имаголошка платформа за разматрање Ковачеве приповетке, међутим, може пружити више-мање плаузибилну слику главног јунака. Изразито је интересантно то што подручје недоречености које је открила психоаналитичка апаратура, маркира и суштинску непостојаност, социјалну исконструисаност идентитета, чак и онако мутних и неразложивих, какав представља фра Веселко Куљић.

Према томе, при анализи Ковачеве приповетке и њеног централног проблема - формираног око лика фра Веселка Куљића - сви досадашњи увиди о међусобно условљеним имажима, разлозима за изостајање ме- 
таимагинирања, те начинима путем којих се Фројдов uncanny уплиће у имаголошке слојеве, синтетишу се у великој, идентитетској несводивости књижевног јунака. Како је, дакле, могуће растумачити, а не тек описати назначени процес?

Поводом идентитетских ме́на фра Веселка Куљића, делимичан одговор могу пружити искази приповедача и редактора фратрових записа, у завршници приповетке. Интензивирајући метафизичку потку фратрових преображења, захваљујући апострофирању Бога и супремативне божанске перспективе, приповедач као да премошћује конструктивизам хрватско-српских и католичко-православних односа на примеру једног изнуђеног, такође исконструисаног злочињења.

Најпре, новелистички обрт подразумева бесмислену фратрову смрт. Изведен пред усташку власт, биће осуђен на смрт због тога што је помогао али, као што остаје непознато, и убио Мира Ножицу, „Србина и комунисту” (Ковач 2001: 263), дакле двоструко алијенираног Другог. Суочен са оптужбама, фратар ће одговорити да никакве примедбе на њих нема. Шта нам ово говори? Стиче се утисак да се фратар суочава и са бесмислом социјално конструсане мржње чији је спроводитељ све време био. Приповедач се, најзад, осврће на сентенцу из фратрове бележнице, а која би могла служити као мото за целокупан његов удес: „Ноћ живота је недоказива" (Ковач 2001: 264).

Ковач сугерише на метафизичко покриће подвојености свог јунака као на теодицејски проблем. У фратровом одбијању да пред џелатима - а који су, што није безначајно, припадници његове матичне националне и конфесионалне заједнице - наведе као ослобађајући аргумент комплексну и недоказиву природу свог ноћног бића, огледа се његова помиреност са чињеницом хаотичног зла међу људима.

Тада у изесном смислу долази до замене о којој у контексту „филозофије зла" пише Лаш Свенесен: уместо метафизичке инстанце Бога, оправдање за зло представља историја, дакле простор и време људског деловања, због чега у модерном свету фигурира „историја као секуларна теодицеја" (Свенсен 2006: 60). Као концепт, сама историја је способна да, попут некадашњег Бога, аргументује чињеницу зла на Земљи. Из тог разлога је скретање пажње на Господа Бога у завршници приповетке „Дан и ноћ” могуће ишчитавати као иронично у вишем смислу.

За имаголошку перспективу ово је од немале важности, јер се лик фра Веселка Куљића негативним одређивањем према историјској стварности чији је до тада био део, на посебан начин претвара у фигуру апатрида бездомника и изгнаника из властитог народа. Апатридност као именитељ, 
у овом случају не може значити само регуларну дистанцираност или мањак емотивне релације према домовини/отаџбини. Фратар у завршници делује више контузовано него самосвесно искључен из слике наказног хрватства у склопу усташке идеологије.

Како национално, тако конфесионално опредељење, сами по себи, лик фра Веселка формативно одређују много више него што исте категорије учествују у прототипу модерне стварности. Самим тим, изненада изнађена апатридност за лик фратра има епифанијску вредност.

Позиција апатрида компримована је у онај фратров одговор „Немам!” (Ковач 2001: 264). Немајући приговора на сопствену смрт, он пред читаоцем, мада крајње имплицитно, раскринкава произвољност и перформативност националних и конфесионалних иденитета, којима претпоставља несхватљиво дејство историје које је попримило нови, перфидан облик, на начин на који је то описано.

\section{Закључак}

Има ли се у виду то да је манијакалност и, у извесном смислу, књижевна изузетност лика фра Веселка Куљића интенционално смештена у окриље једног историјски подробно документованог раздобља насиља и ванредне националне мржње на којој је НДХ почивала, јасном се испоставља релација имаголошког приступа и према историјској науци. Премда у овом раду, из намере да се не угрози алегоричност фратрове судбине, није био наглашен овај сегмент индердисциплинарног резона, ипак чињеница да лик фратра-злочинца има прототипски корелат у низу католичких кољача какви су познати историји, има посебну тежину. Уосталом, по овом питању довољно је консултовати поглавље „Терор и католичење” (Новак 1986: 599-804) из Magnum crimen-a Виктора Новака. У њему је скренута пажња на злочине из редова католичког свештенства које је подржавало пројекат НДХ. Ако ништа друго, управо прецизан одабир специфичног прототипа указује на Ковачеву намеру да се приповетка „Дан и ноћ” не чита само као модернистички профилтрирана алегорија, већ и као хуманистички коментар на злочине Другог светског рата.

Нарочито је подстицајно, сходно претходним опсервацијама, приметити до које је мере комплексна суспрегнутост имаголошких слојева приповетке „Дан и ноћ” са њеним историозофским и метафизичким подручјем интересовања. Указана могућност на специфичан начин верификује књижевну имагологију као интердисциплинаран приступ који, на конкретном примеру Ковачевог текста, не сме остати на дескриптивној разини 
појмова имажа и стереотипа, ни, у одређеној мери, појмова алтеритета и алијенитета. Напротив, без потпорне дијалектике са дериватима психоанализе (uncanny, „велико Друго” и сл.) или теодицејским филозофемама, острањени лик фра Веселка Куљића не би се могао поближе сагледати. Поврх тога, неколика теодицејска питања била су покренута током оваквог херменеутичког „кружења”. Захваљујући одговарању на њих, текст Мирка Ковача се у овом раду указао у свој својој интелектуалној, али и артистичкој изазовности.

\section{ИЗВОРИ И КОРИШЋЕНА ЛИТЕРАТУРА}

Бити 2000: V. Biti, Pojmovnik savremene književne i kulturne teorije, Zagreb: Matica hrvatska.

Брубејр, Купер 2003: R. Brubejr, K. Frederik, „S onu stranu identiteta”, prev. Jelena Stakić, u: Reč, LXIX/15, Beograd, 405-451.

Бужињска, Марковски 2009: A. Burzyńska, P. Markowski, Književne teorije XX veka, Beograd: Službeni glasnik.

Ђурић 2017: М. Ђурић, Модернизација српске прозе 20. века у односу на стваралачку рецепцију књижевног дела Џејмса Џојса: докторска дисертација, Београд: Универзитет у Београду / Филолошки факултет.

Калезић Ђуричковић 2014: S. Kalezić Đuričković, „Romani Mirka Kovača”, u: Croatica et slavica Iadertina, X/11 (2014), Zadar, 319-330.

Ковач 2001: M. Kovač, Najlepše pripovetke Mirka Kovača, izbor i predgovor: Vesna Janković, Beograd: Prosveta.

Милутиновић 2012: D. Milutinović, „U tamnici jezika: Lakanov psihoanalitički koncept”, u: Godišnjak za srpski jezik, XXV/12, 199-206.

Мишић 1963:3. Мишић, Песничко искуство: реч и време II, Београд: Нолит.

Новак 1986: V. Novak, Magnum crimen: pola vijeka klerikalizma u Hrvatskoj, Beograd: BIGZ.

Свенсен 2006: L. Svensen, Filozofija zla, Beograd: Geopoetika.

Секеруш 2001: P. Sekeruš, „Govor o drugom u francuskoj kulturi prve polovine XIX veka: imagološki ogled”, u: Polja, XLVI/418, 51-64.

Смит 1998: E. Smit, Nacionalni identitet, Beograd: Biblioteka XX vek. Фројд 2003: S. Freud, „The Uncanny”, u: The Uncanny, London: Penguin, 123-162.

Чањи 1987: E. Čanji, „U potrazi za dvojnikom: Nebeski zaručnici Mirka Kovača”, u: Polja, XXXIII/345, 494.

$<$ http://imagologica.eu/aboutimagology > приступ: 10. 06. 2018. 
Milan D. Vurdelja

\author{
"THE UNPROVABLE NIGHT OF LIFE": IMAGOLOGICAL \\ ASPECTS OF MIRKO KOVAČ'S SHORT STORY DAY AND NIGHT
}

\title{
Summary
}

Mirko Kovač's thematic preoccupations such as various forms of violence, power or disintegration of ideologies, or confrontation between principles of Eros and Thanatos, interpolate with a complex problem of one's relations towards the otherness. This paper examines the described problem as a highlighted motive in Kovač's literary imaginarium, but dominantly as a part of his short story Day and night. The author of the paper also takes into consideration the context of Kovač's books like Wounds of Luka Mestrevic, Malvina, or Doors of the womb and marks primary imagological, and secondary psychoanalytical aspects of Kovač's short story.

Key words: Heavenly fiances, Mirko Kovač, uncanny, crime, theodicy, the performativity of identity. 